\title{
THIN-FILM SILICON SOLAR CELLS FOR SPACE APPLICATIONS: RADIATION HARDNESS AND APPLICATIONS FOR AN INTEGRATED SOLANT (SOLAR CELL - ANTENNA) MODULE
}

\author{
J. Kuendig, M. Goetz, X. Niquille, A. Shah, \\ Institute of Microtechnology (IMT), University of Neuchâtel, CH-2000 Neuchâtel, Switzerland \\ S. Vaccaro, J. Mosig, \\ LEMA, Ecole Polytechnique Fédérale (EPFL), CH-1015 Lausanne, Switzerland \\ L. Gerlach, P. de Maagt, E. Fernandez \\ Esa-Estec, Keplerlaan 1, NL 2200 AG Noordwijk, The Netherlands
}

\begin{abstract}
A new device called "Solant" (for SOLar cell ANTenna) is presented in this paper. It is a combination of thin-film amorphous silicon solar cells and flat printed antennas.

A proton irradiation campaign has also been carried out on a series of $n$-i-p amorphous and $p$-i-n micromorph [microcrystalline $(\mu \mathrm{c}-\mathrm{Si}: \mathrm{H})$ and amorphous (a-Si:H)] silicon tandem solar cells. The effect of thermal annealing on solar cells degraded by proton irradiation is investigated.
\end{abstract}

\section{INTRODUCTION}

Solar cells and high-gain antennas are often in competition for the available surface in satellite systems. This is becoming a serious tradeoff issue in commercial satellites where size, but also weight should be as small as possible. It was therefore our goal to combine solar cells and antennas within a single unit. This combination was first demonstrated by placing commercial solar cells next to a patch antenna [1]. The present approach is a more advanced concept, in which specifically designed solar cells are being integrated into flat printed antennas. The first part of this paper is dedicated to the solar antennas.

From a more general point of view, we can state that thin-film solar cells are promising candidates for space applications; especially in situations, where the power/weight ratio has to be maximised. Amongst thin-film solar cells, a-Si:H solar cells are particularly interesting, first, because of first tests putting in evidence their excellent radiation hardness [4-7] and, second, because they can easily be deposited on thin, lightweight substrates (thin stainless steel, polyimide foil).
Nevertheless, a-Si:H solar cells have a relatively low power to surface ratio, because their stabilized AM0 efficiency value can hardly surpass the $10 \%$ bar (Note: the end of life - EOL - efficiency of classical space cells can also be quite near to this value). Up to now only amorphous silicon solar cells have been used for the fabrication of our Solant prototypes.

Novel thin-film silicon tandem solar cells incorporate not only a-Si:H but also $\mu \mathrm{c}$-Si silicon (so called "micromorph" solar cells [8-11]). They hold the promise of achieving significantly higher efficiencies (around $15 \%$ for terrestrial applications) and thus, a better power to surface ratio. However, little was known up to now about the radiation hardness of the $\mu \mathrm{c}-\mathrm{Si}: \mathrm{H}$ bottom cell of such a tandem. The second part of this paper is dedicated to describing the results of a proton irradiation campaign carried out on amorphous and micromorph thin-film silicon solar cells.

\section{SOLANT VI prototype}

The purpose of the integration of solar cells and antennas is to optimize the available surface for both communication and power generation. In printed array antennas, the radiating regions (where no solar cells can be placed) are well delimited. The rest of the surface could, thus, be covered by solar cells.

The advantages of this concept are (1) the low weight of the complete device (2) the excellent use of the available surface and the very high Watt/kg ratios. The result is a circularly polarized phased-array antenna based on the slot technology, combined with thin-film amorphous silicon solar cells, creating a new device called "SOLANT" (SOLar cell - ANTenna) module. The feasibility of this concept has been proven within the ESA-project SOLANT [2,3]. 


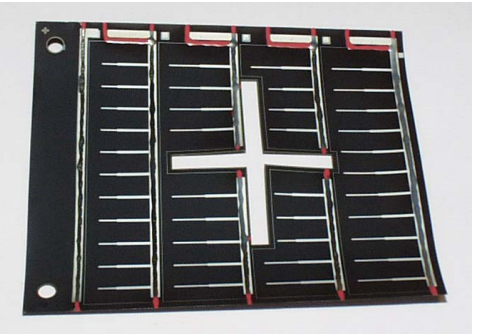

Fig. 1. Solar cell (a-Si:H) module base unit for Solant VI

Several prototypes of SOLANTs were fabricated. The last development of this concept is presented here: the prototype SOLANT VI. This SOLANT is $11.2 \mathrm{~mm}$ thick and the antenna's uppermost level consists of a copper layer in which an array of six slots (in form of crosses) has been cut. On top of this level, six solar cell modules base units (Figs. 1 \& 2) are glued and connected together. The solar modules power an amplifier which is directly integrated onto the backside of the antenna.

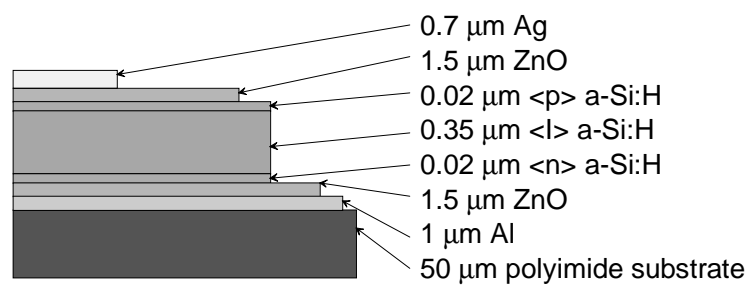

Fig. 2. Structure of the a-Si:H solar cells (not to scale)

Characteristics of the solar module (terrestrial STC, $100 \mathrm{~mW} / \mathrm{cm}^{2}, 25^{\circ} \mathrm{C}, \mathrm{AM} 1.5$ spectrum): $\mathrm{V}_{\text {oc AM1.5 }}=9.94 \mathrm{~V}$, $\mathrm{I}_{\mathrm{sc} A \mathrm{AM} 1.5}=165 \mathrm{~mA}, \mathrm{FF}_{\mathrm{AM} 1.5}=50 \%$. At the maximum power point (MPP) a current of $122 \mathrm{~mA}$ was measured at 7.0 Volts $(821 \mathrm{~mW})$. We have calculated the characteristics of the module for typical space conditions $\left(135 \mathrm{~mW} / \mathrm{cm}^{2}\right.$, $70^{\circ} \mathrm{C}$, AM0 spectrum). We have obtained the following values: $\mathrm{V}_{\text {OC AMO }}=9.19 \mathrm{~V}, \mathrm{I}_{\mathrm{Sc}} \mathrm{AMO}=208 \mathrm{~mA}, \mathrm{FF}_{\mathrm{AMO}}=47 \%$. This results in a power of $899 \mathrm{~mW}$ at the MPP for space conditions, power which is by far enough to supply the amplifier integrated on the back of the antenna.

Characteristics of the antenna: $6 \times 1$ elements phased array working at $3.85 \mathrm{GHz}$. The beam is tilted of $15^{\circ}$. The circularly polarized single element consists of a cross slot excited with a single line. An MMIC amplifier is integrated in the antenna. The antenna gain is $11 \mathrm{dBi}$ (passive) and $31 \mathrm{dBi}$ with the MMIC.

Concept of integration: The ground plane (with the slot crosses) of the antenna is printed on the antenna substrate, and then the solar cells modules are glued on it. In the breadboard, two solar modules base units are connected in parallel and three such pairs in series.

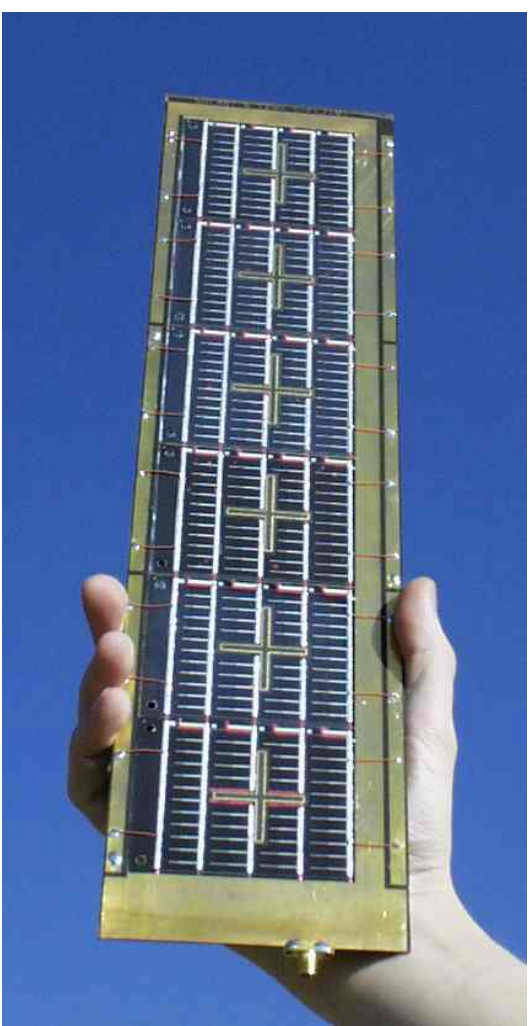

Fig. 3. Solant VI prototype $(42 \times 9.6 \times 1.1 \mathrm{~cm})$

\section{RADIATION HARDNESS OF THIN-FILM SILICON SOLAR CELLS FOR SPACE APPLICATIONS}

Solar cells in space are highly exposed to proton radiations. It has been shown recently that CIS [11] and thin-film amorphous silicon [4-7] solar cells have good radiation hardness compared to conventional $\mathrm{Si}$ and GaAs devices. The power/weight ratio of thin-film solar cells is very promising for space applications, where weight is an important cost factor. Thin-film double junction solar cells using amorphous silicon (a-Si:H) and micro-crystalline silicon $(\mu \mathrm{c}-\mathrm{Si}: \mathrm{H})$, i.e. so called "micromorph" tandem

\begin{tabular}{|c|c|}
\hline Back reflector & \\
\hline $\mathrm{n} 2$ & \multirow{3}{*}{$\begin{array}{c}\mu \mathrm{c}-\mathrm{Si}: \mathrm{H} \\
\text { (bottom } \\
\text { cell) }\end{array}$} \\
\hline i2 & \\
\hline p2 & \\
\hline $\mathrm{n} 7$ & \multirow{5}{*}{$\begin{array}{l}\text { a-Si:H } \\
\text { (top } \\
\text { cell) }\end{array}$} \\
\hline ¡ & \\
\hline pl & \\
\hline TCO & \\
\hline $\begin{array}{c}\text { Glass } \\
\text { substrate }\end{array}$ & \\
\hline
\end{tabular}

Fig. 4. Cross section of double junction $\mathrm{p}-\mathrm{i}-\mathrm{n}$ micromorph

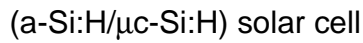


cells [8-10] could be a promising candidate for satellites but their radiation hardness was so far not known. A series of irradiation experiments was therefore conducted. Our test samples are thin film $n$-i-p amorphous and $p$-i-n micromorph silicon solar cells deposited on different types of substrates.

The structure of the micromorph devices is illustrated in Fig 4. All the devices were manufactured by the Very High Frequency Glow-Discharge (VHF-GD) technique [12] at IMT Neuchâtel. Prior to starting the irradiation process, all cells were annealed at $180^{\circ} \mathrm{C}$ for 90 minutes. The pre-irradiation conversion efficiency was between 7.5 and $8.5 \%$ for the a-Si:H cells and between 10 and $11 \%$ for the micromorph cells.

Our solar cells were irradiated by the European Space Agency (ESA) at CEA (Paris). All cells were irradiated under open-circuit conditions, for the a-Si:H through the front side ( $p$-side) and for the $p$-i-n micromorph cells through the back side (n2-side). The fluence (quantity of particles per area) was $1.5 \mathrm{E} 13 \mathrm{p}+/ \mathrm{cm}^{2}$. The energy spectrum of the incident protons is shown in Fig. 5.

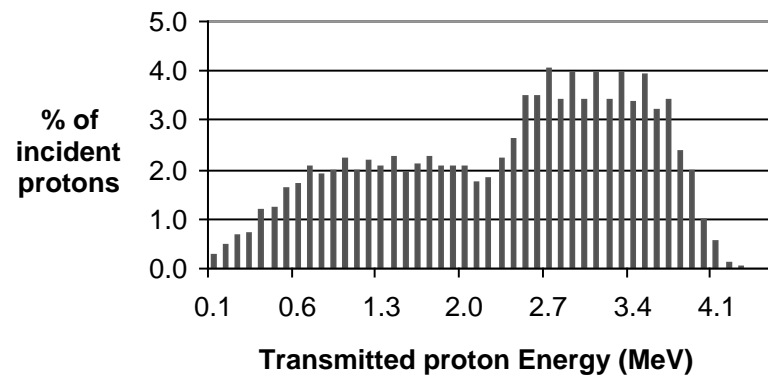

Fig. 5. Energy spectrum of the incident protons

Compared to the typical irradiation energy of 10 $\mathrm{MeV}$, the spectrum is shifted to lower energies, which are potentially more harmful for thin-film solar cells. After irradiation, annealing steps at increasing temperatures have been carried out.

The cells were characterized before and after irradiation, and after the post-irradiation annealing steps. This was done at the IMT with a solar simulator under AM1.5 conditions $\left(1000 \mathrm{~W} / \mathrm{m}^{2}\right.$, standard terrestrial conditions STC) and with spectral response measurements. Three parameters were measured: the open circuit voltage (Voc), the short circuit current (Isc), and the fill factor (FF). A fourth parameter is calculated: the efficiency $(\eta)$. The difference for AMO (space) conditions (illumination in space: $1360 \mathrm{~W} / \mathrm{m}^{2}$ ) would be an increase by $22 \%$ of $\mathrm{I}_{\mathrm{sc}}$, and a small reduction of $\mathrm{FF}$ and $\eta$. Comparisons are made w.r.t. the mean value of the normalized conversion efficiency of six cells from the same substrate for each sample.
For the $n-i-p$ amorphous silicon solar cells (on polyimide, stainless steel sheet-metal and glass substrates), the results show that these cells are only very slightly damaged by proton irradiation at the chosen fluence and energy. The efficiency loss is only a few percent $(3-5 \%)$, and it is immediately recovered by annealing at $100^{\circ} \mathrm{C}$.

For the micromorph solar cells (on glass substrates), all three parameters show an important loss after the proton irradiation. Fig. 6 presents normalized efficiency of $p$-i-n micromorph solar cells on glass substrates after proton irradiation and after subsequent annealing at different temperatures $\left(100^{\circ} \mathrm{C}\right.$ for 5 hours, $140^{\circ} \mathrm{C}$ for 2 hours, $180^{\circ} \mathrm{C}$ for 2 hours). Experimental results of two different samples are illustrated. The degradation induced by the proton irradiation could be almost completely recovered with the post-irradiation annealing steps.

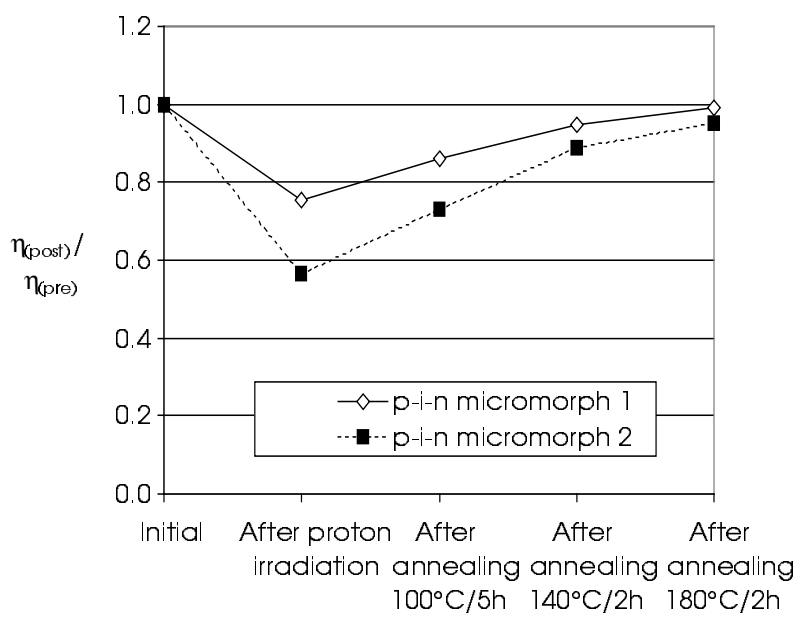

Fig. 6. Normalized efficiences of p-i-n micromorph solar cells on glass substrate

For the p-i-n micromorph tandem solar cell, the spectral response measurements show that it is the microcrystalline (bottom) cell that is damaged after the proton irradiation (Fig. 7). An explanation for this could be found in the different thicknesses of the amorphous and microcrystalline layers of the tandem micromorph cell. As the microcrystalline layers (bottom cell) are about 10 times thicker than the amorphous layers (top cell), there is a higher probability to find radiation-induced damages located at some place along the collection path within the microcrystalline layers. The fact that amorphous material has originally a lot of internal defects and that these solar cells are designed to work with these defects (e.g. by having a higher internal field) could also explain that amorphous layers are much more radiation-resistant than microcrystalline layers. 


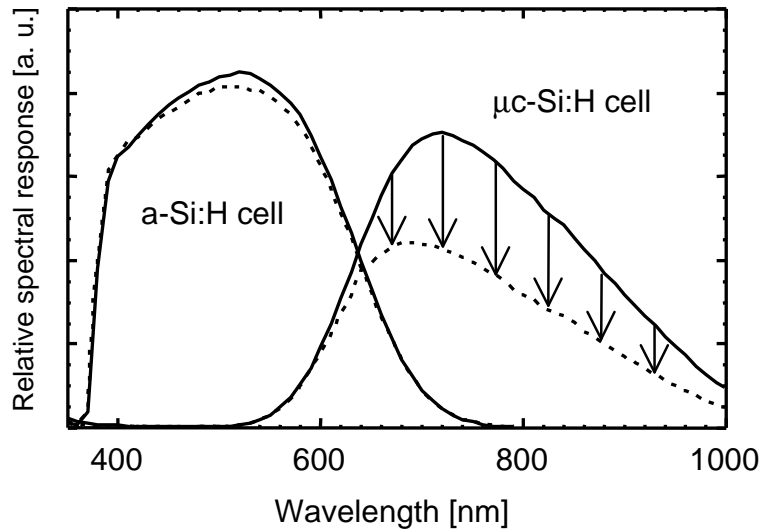

Fig. 7. Relative spectral response [a. u.] versus wavelength $[\mathrm{nm}]$ for the $p$-i-n micromorph cell (dotted line $=$ measurement after proton irradiation)

The capacity of microcrystalline solar cells to recover after thermal annealing was a surprise for us. It is possibly due to the presence of hydrogen within these plasma-deposited microcrystalline layers.

The micromorph cells of the first irradiation experiment (fig. 6) have been exposed a second time to the exactly same proton irradiation. After this second bombardment, we have annealed the samples at significantly lower temperatures $\left(70^{\circ} \mathrm{C}, 100^{\circ} \mathrm{C}\right.$ and $130^{\circ} \mathrm{C}$, each annealing step during 10 hours). Experimental results of the same two samples are illustrated in Fig. 8. It shows that after annealing at lower temperatures $\left(70^{\circ} \mathrm{C}\right.$, $100^{\circ} \mathrm{C}$ and $130^{\circ} \mathrm{C}$ ) the degradation due to proton bombardment could be partly recovered. We expect that longer annealing times at temperatures around 70 to $100^{\circ} \mathrm{C}$ may allow the full recovery of the degradation. It is likely that a steady state will be reached in space, where simultaneous degradation and annealing come to a balance.

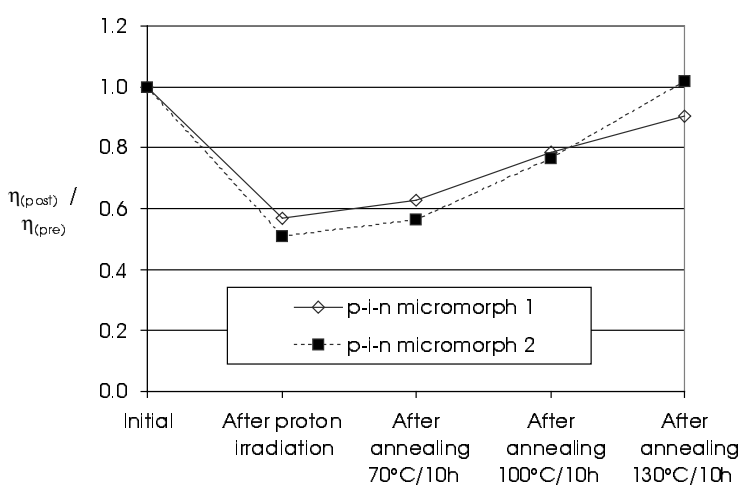

Fig. 8. Normalized efficiencies of p-i-n micromorph solar cells on glass substrates

\section{CONCLUSIONS}

Up to now, we have manufactured different prototypes of SOLANT (SOLar cell - ANTenna module) using a-Si:H solar cells. Radiation hardness of thin-film amorphous silicon solar cells is excellent, but they have a relatively low power to surface ratio. The use of micromorph tandem solar cells, which hold the promise of significantly higher efficiencies (up to $10 \%$ steady-state space efficiency), could result in a much better power to surface ratio. Although these micromorph solar cells showed an important loss of efficiency immediately after the proton irradiation experiment, they could also be used in space applications. This is due to the fact that the operating temperature of space cells can be up to $100^{\circ} \mathrm{C}$ (modules without heat-reflecting cover layers) and we suppose that an extended annealing at this temperature could recover the full degradation. The thermal history of the solar modules in space is therefore very important. Further research should de done to clarify the interaction between degradation and recovery as a function of temperature.

The work reported was carried out in part under contract No. $12879 / 98 / \mathrm{NL} / \mathrm{NB}$ ot the European Space Agency.

\section{REFERENCES}

[1] M. Tanaka et al., "Microstrip antenna with solar cells for microsatellites", Electronics Letters, 31, 1995, pp. 5-6

[2] S. Vaccaro et al., "Integration of antennas and solar cells for satellite communications", AP 2000, Davos

[3] S. Vaccaro et al., "Integrated solar panels antennas", Electronics Letters, 36, 2000

[4] S. Guha et al., "Amorphous silicon alloy solar cells for space applications", $2^{\text {nd }}$ WCPEC, Wien, Austria, 1998

[5] G. J. Vendura et al., "Irradiation and annealing of amorphous silicon space cells", 2 $2^{\text {nd }}$ WCPEC, 1998

[6] G. Oomen et al., "The effects of extremely high radiation fluxes on amorphous silicon alloy cells", $\quad 2^{\text {nd }}$ WCPEC, 1998

[7] J. Kuendig et al., "Effect of proton irradiation on the characteristics of different types of thin-film silicon solar cells", $16^{\text {th }}$ EPVSEC, 2000

[8] N. Wyrsch et al., "Development of inverted micromorph solar cells", $2^{\text {nd }}$ WCPEC, 1998, pp. 467-471

[9] J. Meier et al., "Microcrystalline and micromorph thinfilm silicon solar cells", $2^{\text {nd }}$ WCPEC, 1998, pp. 375-380

[10] J. Meier et al., "Microcrystalline/micromorph silicon thin-film solar cells prepared by the VHF-GD technique", PVSEC 11, 1999

[11] H. Schock, K. Bogus, "Development of CIS solar cells for space applications", $2^{\text {nd }}$ WCPEC, 1998, pp. 3586-3589 [12] H. Curtins, N. Wyrsch, A. Shah, "High rate deposition of amorphous hydrogenated silicon: effect of plasma excitation frequency", Electr. Lett. 23, (1987), p. 228-230 